\title{
LACK OF ONE COMMON ADMINISTRATIVE PROCEDURE? IS REGULATION ON THE EU ADMINISTRATIVE PROCEDURE NECESSARY IN THE EU?
}

\author{
Ana ĐANIĆ ČEKO \\ E-mail: adjanic@pravos.hr \\ Assistant Professor \\ Faculty of Law, Josip Juraj Strossmayer University of Osijek, Croatia \\ Tunjica PETrašević \\ E-mail: tpetrase@pravos.hr \\ Associate Professor \\ Faculty of Law, Josip Juraj Strossmayer University of Osijek, Croatia
}

\begin{abstract}
The result of expanding jurisdiction of the European Union (hereinafter: EU) is not only the increase in number of sectors in which special administrative procedures are enforced, but also the increase in number of corresponding bodies and agencies. The current state is characterised by lack of coordination and uniformity and absence of codified procedural rules which makes it difficult for the EU citizens to easily and completely understand their administrative rights and contributes to deterioration of their legal protection. This is not in accordance with the Charter of Fundamental Rights of the European Union (hereinafter: Charter), which guarantees its citizens the right to good administration (Article 41). The authors deem that the standardization of the sectoral administrative rules would lead to simplification and rationalisation of the administrative procedures. European Administrative Law is developed through the practice of the Court of Justice of the EU (hereinafter: CJEU) that has formulated a series of general administrative principles to be followed in order for administrative procedures to maintain their legitimacy. Nevertheless, the legislator is considered to be the one who determines clear procedural rules, thus contributing to legal safety and predictability. Discussing the need for codification of the Law on Administrative Procedure of the European Union (hereinafter: EU APA) has thus become even more relevant. However, the question that constantly arises is whether the regulation on common administrative procedure is necessary in the EU legislation and if so to what extent. The necessity to regulate the minimum of common procedural standards and principles of good
\end{abstract}


administration along with the procedures of EU institutions when resolving individual cases of physical and legal persons is emphasised by the European Parliament Resolution of $15^{\text {th }}$ January 2013 with recommendations to the Commission on the Law of Administrative Procedure of the European Union (2012/2024(INL)). The legal basis contained in the Article 298 (1) of the Treaty on the Functioning of the European Union (hereinafter: TFEU) is also emphasized. This paper will conclude with a brief review of the results of public consultation on the European Union's administrative law.

Key words: EU, procedural rights, sectoral procedures, (European) administrative procedure, administrative principles

\section{Introduction}

Importance of the regulation of administrative procedures of the European Union (hereinafter: EU) is primarily evident due to lack of one procedure applicable by a number of institutions, offices, agencies and bodies of the EU according to common, uniform and universal set of rules in order to insure effective legal protection of guaranteed procedural rights and standards to the citizens. A good system of administrative procedures protects citizens' rights and promotes citizens' participation. It further avoids unnecessarily complicated, formalistic and lengthy processes and enhances transparency and accountability thus contributing considerably to stronger integrity of public administration, since plenty of cases of corruption aim at ensuring nothing else but an administrative decision in compliance with the law and issued in a reasonable time (Rusch, 2014, p. 197). Modern administrative procedure should serve several complementary functions: from guaranteeing the rights of individual parties, their participation in proceedings, and the conciliation of interests, to administrative transparency, collaboration in the system, and administrative efficiency (Kovač, 2016, p. 440).

There are two basic models of EU administrative procedures (direct and indirect). For many reasons both of these models raise the question whether EU Administrative Procedures should be codified (Harlow, 1996, p. $3)$. The necessity of establishing codification of administrative procedures in the form of detailed procedural provisions that would completely govern administrative procedures arises from the fact that EU jurisdiction is growing significantly; the number of its bodies and special administrative areas is being enhance and most importantly the fact that administrative procedures have more than one source by which they are being normalized. The lack of unified procedural rules is evident in the: lack of uniformity; fragmentation; the difficulty EU citizens have to easily and completely understand their 
administrative rights; ${ }^{1}$ and sector-specific rules. Despite of large number of regulations governing the material issues in special administrative areas, there are not any detailed procedural provisions that would govern the entire administrative procedure (Đerđa, 2014, p. 80; Đerđa and Jerčinović, 2020, p. 93). Codification would bring many benefits such as unification, integrative purpose and unified solutions, stabilization, harmonization of fragmentation and modernization of public administration, enhance legal certainty, clarification and simplification of EU law, better regulation, clear procedural rules and especially transparency and effectiveness of the legal system. If designed to reach its potential, it could help simplify the legal system and fill gaps, enhance legal certainty and thereby contribute to compliance with the rule of law, principle of subsidiarity (decision making can effectively take place by de-centralised administrations) and general principles of EU law (Hofmann, Schneider and Ziller, 2014, p. 16).

The task of finding and interpreting administrative procedural provisions in the primary, and secondary, more numerous, EU law as well as EU judicial practice is complex and demanding. Good administration responds to the expectations and requirements of a balanced approach to safeguarding the public interest while respecting the rights and interests of the individual citizen (Rusch, 2014, p. 191). The increasing importance to the principle of good administration when assessing the legitimacy of the activity of the EU Member States is also recognized by the Court of Justice (CJEU). ${ }^{2}$

The first step toward efficient administrative decision-making processes of the European administration is to systematically regulate, through formal codification administrative procedures in one full fledged legislative text. Adequate system of administrative procedures is imperative. Despite the national states common endeavour to remove the administrative barriers, fundamental and modern administrative law principles must be effective and equivalent in the EU administrative procedural law. The question that constantly arises is whether the regulation of common administrative procedure is necessary in the EU legislation and if so to what extent. To have an open and efficient European administration and to avoid

$172 \%$ of respondents say they do not feel informed about the Charter of Fundamental Rights. Satisfaction with the EU administration is generally low when it comes to its effectiveness, service-mindedness, and transparency (42\%). Retrieved from https://www.europarl.europa.eu/at-your-service/hr/beheard/eurobarometer/the-european-ombudsman-and-citizens-rights, https://europa.eu/rapid/press-release_EO-11-14_en.htm, [accessed on 15 April, 2020].

2 Retrieved from https://free-group.eu/2016/02/09/better-administrative-makingwhen-the-european-parliament-pave-the-way-to-a-reluctant-europeancommission/, [accessed on 1 June, 2020]. 
ambiguity and vagueness, it is necessary to regulate the minimum of common procedural standards and principles of good administration along with the procedures of EU institutions when resolving individual cases of physical and legal persons.

This paper is divided into five parts. In the first part, the authors describe the beginning of the European Parliament initiative in compliance with the Proposal for Regulation on Administrative Procedure of the European Union (hereinafter: EU APA). Taking into account numerous scientific discussions, the second part of the paper briefly points out whether there is a valid legal basis for EU APA. The dilemmas and uncertainties that appear regarding the codification process of EU administrative procedures are pointed out in the third part. In the following part of the paper, the impact of the European administrative procedural law on the regulation of the national administrative procedures and the European Dimension of Administrative Procedures and the position of National Administrative Procedures in relation to the existence of European Administrative Procedural Law is highlighted. The purpose of this paper is not to scrutinize the idea of codification but to discuss current issues such as the necessity of the codification process; a valid legal basis for the European administrative procedural code, the so called EU APA; the applicability of EU APA to EU institutions or/and member states when applying the EU law. Furthermore, in the fifth part the paper offers insight into the analysis of the results of public consultation about EU APA from 2018. In its final part, the authors present their conclusive considerations regarding the open questions of the issue at hand.

\section{Launch of the Initiative for the Adoption of the Law of Administrative Procedure of the European Union}

The first attempt to design supranational general procedural regulations, on European level, was through the European Code of Good Administrative Behavior, adopted by the EU Ombudsman in 2001 and revised in 2004 and 2012. A further formal landmark in the direction of an APA for the EU was the European Parliament Resolution of 2013 with recommendations to the Commission on a Law of Administrative Procedure of the EU and further Resolution of 2016, including draft Regulation for an Open, Efficient and Independent European Union Administration. Under the influence of modern theories of good governance and good administration, the vast majority of comparable European countries, the EU itself has been turning the relevant regulation into a legally defined and politically-sociologically driven societal process. The European Parliament follows a similar trend in an attempt to draft the EU APA as the single legal instrument to be applied at the level of the EU institutions (Sever \& Kovač, 2016, p. 2). 
The debate about the codification of the European administrative procedure has long been held in the academic circles, but in 2012 it became a political matter. One of the first discussions referring to codification was organized by the European University Institute in 2005 in Florence (Cananea, 2018, p. 283). In 2012, the Committee on Legal Affairs of the European Parliament developed a draft of the resolution, adopted by the Parliament in 2013, ${ }^{3}$ which proposed to the Commission that the European APA be adopted along with the draft. According to this proposition, the Parliament emphasized the Article 298 UFEU as the legal basis of the draft, whereas the code should be applied in cases where there are no specific rules for particular administrative area provided that the sectorial rules do not offer less protection than the APA. The issue that immediately arose was what influence the code will have on the legal systems of the member states that mostly have their own laws regarding the (general) administrative procedure (Rusch, 2009, p. 5, 8; Vučetić, 2018, p. 202-203; Wierzbowski, 2019, p. 2, Hoffman, Schneider and Ziller, 2014, p. 9-10).

ReNEUAL (abr. for the Research Network on EU Administrative Law) ${ }^{4}$ has meanwhile formed its own proposition different from that of the Parliament, - the so-called Model Rules on EU Administrative Procedure (Craig, 2013, p. 4). The Model Law is more far-reaching and offers two options as plans for solutions to the issues under discussion. According to plan A, the code would be binding for member states when applying the EU law which is within the reach of the EU rights. According to plan B, member states would be excluded from the code.

The first proposition was made by the politicians, whereas the other, Model Law, was proposed by administrative law experts from the EU member states.

The EU system for public decision-making is one of a kind and consists of a patchwork of borrowed arrangements, compromises and constitutional oddities. The proper role and function of the European Commission as the EU's administration is hard to define because it is permanently torn between a political one and an objective one (Meuwese,

${ }^{3}$ European Parliament Resolution of 15 January 2013 with recommendations to the Commission on a Law of Administrative Procedure of the European Union (2012/2024(INL)).

${ }^{4}$ ReNEUAL comprises senior and junior scholars of national and EU administrative law from leading institutions throughout Europe and beyond. ReNEUAL is structured into four working groups: 1) rulemaking, 2) single case decision making, 3) contracts and 4) information management \& overall structure. More about see at http://www.reneual.eu/index.php, [accessed on 15 April, 2020]. 
Schuurmans and Voermans, 2009, p. 9). The European Commission presided over by Barros (2009-2014) has taken no specific measures since they recognized no functional necessity for a change. However, the vice president of the new Commission (2014-2019) Frans Timmermans has mentioned this as a possibility. As an answer to a parliamentary question (E-001249-16), ${ }^{5}$ he has stated that the Commission is open for the possibility does exist to be convinced that the necessity for the EU APA. ${ }^{6}$ Parliament afterwards adopted the new resolution 2016/2610 (RSP) ${ }^{7}$ with the aim of highlighting the necessity of comprehensive and cross-cutting administrative procedure. In his European Parliament resolution of 26 October 2017 on monitoring the application of the EU law 2015 (2017/2011 (INI)), Timmermans repeated the call for the Commission to provide a specific proposition of the APA. Meanwhile, in December 2017, the Parliament started a public debate on general rules for an open independent and efficient European administration.

As a follow-up to the European Parliament resolution of 9 June 2016, the Parliament's Committee on Legal Affairs asked the European Parliamentary Research Service's European Added Value Unit to carry out a public consultation. The aim of the consultation was to survey public opinion. The Parliament received 166 fully completed online responses from $20 \mathrm{EU}$ Member States. ${ }^{8}$ The key findings of the public consultations will be summarized in chapter 4 of this paper.

\section{Is there Valid Legal Basis for EU APA?}

It is an indisputable fact that there was no justified legal basis for codification of the administrative procedure within the EU until the Treaty of

5 Retrieved from http://www.europarl.europa.eu/legislative-train/theme-union-ofdemocratic-change/file-eu-administrative-procedure, [accessed on 17 April, 2020].

${ }^{6}$ Answer given by First Vice-President Timmermans on behalf of the Commission Question reference: E 001249/2016. Retrieved from https://www.europarl.europa.eu/doceo/document/E-8-2016-001249-

ASW_EN.html?redirect, [accessed on 17 April, 2020].

${ }^{7}$ European Parliament resolution of 9 June 2016 for an open, efficient and independent European Union administration (2016/2610(RSP)). About the context and legal elements of the Proposal for a Regulation from 2016 see more https://u4unity.eu/document2/IPOL_STU(2016)536487.pdf, p. 12-33, [accessed on 5 June, 2020]

${ }^{8}$ See European Parliamentary Research Service - European Added Value Unit; EU law for an open independent and efficient European administration Summary report of the public consultation, PE 621.830 - July 2018, p. 1. Retrieved from https://www.europarl.europa.eu/RegData/etudes/STUD/2018/621830/EPRS_ STU(2018)621830_EN.pdf, [accessed on 25 April, 2020] 
Lisbon (2009) was signed. However, it is still disputable whether one currently exists. Different attitudes regarding the question at hand are analysed in the following paragraphs.

The European Added Value Assessment from 2012 was the predecessor of the Parliament Resolution of 13 January 2013. ${ }^{9}$ The legal basis was found in the Article 41 of the Charter of Fundamental Rights of the European Union (hereinafter: Charter) and in the Article 298 of the Treaty on the Functioning of the European Union (hereinafter: TFEU). Article 41 of the Charter guarantees the right to good administration. This means that every person has a right to have an independent body reaching the decisions regarding their rights and obligations in the legal procedure and within a reasonable deadline, however, it is not stated how this is to be accomplished.

On the other hand, Article 298 Paragraph 2 of the TFEU provides Union the authority to regulate relations between EU institutions and administration, but the aim of this provision is, according to some authors, purely internal (Ploeg, 2014, p. 1). The prominent expert on the EU law, Paul Craig considers that Article 298 of the TFEU could be the basis with additional support in the Convention on the Future of Europe and in the final report of the working group $\mathrm{V}$ on complementary competences, which recommended the implementation of the provision. Craig explains three possible interpretations of the Article 298 of the TFEU. The first and the narrowest interpretation, which Craig discards, allow the implementation of the legislation as purely internal. It regulates only the relations between the institutions without regulating the procedural rights of the third parties affected by the decisions reached by the EU bodies thereby obligating only the Union institutions. According to the second interpretation, Article 298 enables the implementation of the procedural legislation, but is, as such, only applicable on EU institutions, bodies, offices and agencies. Lastly, the third interpretation is based on the second, however, includes national bodies when operating within the reach of the EU rights. Craig finds support for this last interpretation in the Article 298 Paragraph 1 that mentions "European Administration", which according to his interpretation, also includes national bodies of the member states. The expression used refers to European administration and not European Union administration.

Supporting his claim, he highlights the composite procedures. One of the central challenges for regulating EU administrative procedures is finding solutions for the forms of intense procedural cooperation between national

9 European Added Value Assessment Law of Administrative Procedure of the European Union, European Added Value Unit (ed.), pp. 1-26. Retrieved from http://publications.europa.eu/resource/cellar/230193b6-a913-45a5-88536cb4ca9042cb.0004.02/DOC_1, [accessed on 25 April, 2020] 
and European administrative actors through 'composite procedures' characterised by multi-jurisdictional input into decision-making (Hofmann, Schneider and Ziller, 2014, p. 1). Administrative procedures in the EU law are, frequently integrated with national administrative bodies of member states and institutions of the Union participating in them. Such procedures are called composite procedures. In the stage of reaching the final administrative act, participation of either national or EU institutions is obligatory according to the procedure proscribed on different levels. By doing so, the network of national administrative and $\mathrm{EU}$ bodies is formed enabling mutual collaboration and exchange of information. According to Hofmann, composite procedures are "a specific form of highly integrated administrative procedural cooperation for implantation of the EU policies" (Hoffman, 2009, p. 166). These procedures are present in the following areas: product safety, technical safety, genetically modified organisms, public procurement, asylum processes. The complexity of the procedures at the same time means more problems and frequently even an informal exchange of information can make the judicial supervision quite challenging (Hoffman, Schneider and Ziller, 2014, p. 7, p. Eliantonio, 2014, p. 100).

The Parliament analysis associates Article 41 with the Article 298 of the TFEU, but it is not stated that they guarantee explicit legal basis for adopting the European administrative procedural code. The question that imposes itself is whether it is necessary to change the founding treaties in order to pass the EU APA? According to Article 352 of the TFEU which talks about implied powers of the Union this is not the case:

I. If action by the Union should prove necessary, within the framework of the policies defined in the Treaties, to attain one of the objectives set out in the Treaties, and the Treaties have not provided the necessary powers, the Council, acting unanimously on a proposal from the Commission and after obtaining the consent of the European Parliament, shall adopt the appropriate measures. Where the measures in question are adopted by the Council in accordance with a special legislative procedure, it shall also act unanimously on a proposal from the Commission and after obtaining the consent of the European Parliament.

II. Using the procedure for monitoring the subsidiary principle referred to in Article 5(3) of the Treaty on European Union, the Commission shall draw national Parliaments' attention to proposals based on this Article. 
Lack f one common administrative procedure?...

III. Measures based on this Article shall not entail harmonisation of Member States' laws or regulations in cases where the Treaties exclude such harmonisation.

IV. This Article cannot serve as a basis for attaining objectives pertaining to the common foreign and security policy and any acts adopted pursuant to this Article shall respect the limits set out in Article 40, second paragraph, of the Treaty on European Union.

As can be seen in the provision Article 352 (1), the Union may reach an act even though it lacks authority, provided it is necessary for contracting aims to be realized. However, it is required that the decision is unanimously reached, and certain additional conditions defined in Paragraphs 2-4 are fulfilled. Craig considers the additional conditions have been fulfilled (Craig, 2013, p. 11).

\section{Doubts and Dilemmas on the Proposal of the European Parliament on the} Need for Codification of the Administrative Procedure of the EU

Craig considers both propositions, that of the Parliament and the Model Law, are a result of comparative research of legal order of the member states and should, therefore, not be viewed as "imposed from above and foreign" to the legal orders of the member states. The fact is that member states are already bound by certain principles, - general law principles developed by the EU court when working within the laws of the Union (Petrašević, 2012, p. 793-807). The only difference is that now member states do this by applying their own administrative procedural rules, whereas according to plan A of the Model Law, they would have clear supranational rules. Furthermore, Craig considers that including member states in plan A of the Model Law is nothing new, but just a mere reflection of the current state where the member states are already included in the application of the Union law (Craig, 2013, p. 8).

The EU APA would simplify the procedure for all those obligated to apply the material law of the EU in a way that would make for clear procedural rules. Including member states in applying the EU law is nothing new. However, there is a principle of national procedural autonomy. The EU court has, in its early stages of integration, developed the principle of supremacy, direct effect of the Union law and defined the obligations, primarily those of the national courts. ${ }^{10}$ The EU court has decided that national courts are obligated to do this according to their own procedural rules while in compliance with the equivalence and effectiveness principle. This is the so-called principle of Procedural Autonomy of the EU Member States that

${ }^{10}$ See court cases 626/62 Van Gend en Loss, ECLI: ECLI:EU:C:1963:1 i 6/64 Costa v. ENEL, ECLI: ECLI:EU:C:1964:66. 
has an extensive judicial practice in the EU courts (Lenaerts, Maselis and Gutman, 2015, p. 109). This principle does not question the justification of the codification itself, but it raises doubt about whether EU APA should be legally binding to the bodies of the member states. The EU APA is restricted to the EU institutions and do not apply to the Member States, unless they are implementing Union law. However, Sever and Kovač emphasizes that through case law Charter and EU APA can also have a broader convergence effect at the national level. That is, considering the convergent development of administrative law and codification of the EU-related documents on the level of principles, these principles and rights can well serve as a reference the modern national codification of APs or as an example of good practice for other entities (Sever \& Kovač, 2016, p. 4). EU APA could offer useful framework for the EU Court and legal certainty for EU citizens. But more important (or ideally), it could steer the development of EU administrative law in a direction that fosters a transparent and fair exercise of regulatory governance (Meuwese, Schuurmans and Voermans, 2009, p. 31).

Craig considers the arguments against codification as diverse, but they can, nevertheless, be divided into two major categories: the first group considers codification completely unnecessary; the second claims that codification has negative on the effects on pluralism of administrative procedures of member states. The first argument against codification is based on the premise that existing current state is fine and satisfying. As special problem occurs with composite administrative procedures, where even the administrative law experts must make an effort in order to provide answers to specific questions. Regarding the second argument, that codification has negative effects on pluralism of administrative procedures of member state Craig thinks that preserving national sovereignty and pluralism of administrative procedures of member states is important, but it represents nothing new, since the member states have so far had to make compromises in favour of decisions with the aim of achieving specific common goals of the Union. Craig, therefore, considers that no exception should be made regarding the national procedural rules.

Preface of Model Law was written by the first Ombudsman Emily O'Reilly in 2013. She explains why codification is important, so we emphasize:

"As European Ombudsman, the gap between the governing institutions of the European Union and its citizens is my particular concern. Those of us who work in the institutions need to understand that we face a crisis of European citizenship. And one key aspect of that crisis is that many citizens see the EU and its institutions as remote and alien. The enormous work the Research Network in European Union Administrative Law 
(ReNEUAL) undertook and successfully accomplished in drafting Model Rules of administrative procedure helps makes more visible, and more understandable, the administrative framework through which the EU institutions carry out their functions. (...) It is therefore of fundamental importance that ReNEUAL succeeded in avoiding rules that are excessively detailed. The Model Rules do not invite a box ticking approach, nor do they create an obstacle course that inhibits sound judgment or defies common sense. The Model Rules make sense both as a basis for possible future legislation and as a persuasive synthesis of principles to be found in the existing law (...) "..

After having analysed a series of papers and different points of view supporting and opposing codification, benefits and drawback will be shown in the table:

Table 1 Benefits and drawbacks on the need for codification of the administrative procedure of the EU

\begin{tabular}{|l|l|}
\hline \multicolumn{1}{|c|}{ BENEFITS/ADVANTAGES } & \multicolumn{1}{c|}{ DRAWBACKS/ WEAKNESSES } \\
\hline $\begin{array}{l}\text { efficient, simple and speedy } \\
\text { administrative procedures, better } \\
\text { regulation, standardising the sectoral } \\
\text { rules, stabilization }\end{array}$ & $\begin{array}{l}\text { unnecessary formalism (formalistic } \\
\text { bureaucratic) approach), slow down } \\
\text { decision making process }\end{array}$ \\
\hline $\begin{array}{l}\text { reduce of administrative costs and } \\
\text { barriers, adding legitimacy to the process, } \\
\text { unification of minimum standards and } \\
\text { procedural rights }\end{array}$ & $\begin{array}{l}\text { avoiding too detailed and long law } \\
\text { (legislation)-complicated, fragmentation } \\
\text { and complexity of the law in increasing } \\
\text { sector-specific legislation }\end{array}$ \\
\hline $\begin{array}{l}\text { better and easier communication and } \\
\text { cooperation with citizens, precise and } \\
\text { written in simple and understandable } \\
\text { language }\end{array}$ & $\begin{array}{l}\text { confusing for the applicants of the law, } \\
\text { disorientation and confusion }\end{array}$ \\
\hline $\begin{array}{l}\text { appropriate tool to improve } \\
\text { administrative decision-making, } \\
\text { modernization of public administration }\end{array}$ & $\begin{array}{l}\text { hard to read and understand for citizens } \\
\text { lack of systematic approach } \\
\text { subsequent differentiated jurisprudence } \\
\text { of the CJEU }\end{array}$ \\
\hline $\begin{array}{l}\text { clear structure, easy to apply, accessible } \\
\text { to citizens, legal certainty, concern only } \\
\text { administrative activities in the strict sense }\end{array}$ & $\begin{array}{l}\text { operational costs, } \\
\text { rules that are tailor-made, gaps in } \\
\text { applicable rules }\end{array}$ \\
\hline $\begin{array}{l}\text { catalogue of administrative rights, } \\
\text { minimum "safety net of guarantees", } \\
\text { clarification, simplification of EU law, } \\
\text { high quality administration that acts }\end{array}$ & $\begin{array}{l}\text { codification would remove the } \\
\text { flexibility required to adapt to particular } \\
\text { needs }\end{array}$ \\
\hline
\end{tabular}

11 Retrived form http://www.reneual.eu/images/Home/forewordeuombudsman.pdf, [accessed on 20 April, 2020]. 
through efficient, transparent and coherent procedures emphasizes right to good administration, comprehensive content and scope need for changes of national APA's incoherent rules, reduced degree of transparency of procedural rights, pluralisation of administrative actors, multi-jurisdictional implementation of EU policies

Source: author's work

\section{Short Overview on the Report (Evas, 2018, p. 1-76) ${ }^{12}$ of the Public Consultations from July}

The European Parliament "and the academic community" have repeatedly emphasized and stimulated the European Commission ${ }^{13}$ to adopt a legally binding and horizontally applicable EU administrative procedure law. The European Parliament plays an active role in defending citizens' rights to good administration and has undertaken various actions to address the existing problem, including recommendations regarding the need to form EU APA. Parliament's Committee on Legal Affairs (JURI) requested detailed analysis, empirical estimates and impact assessment of action on EU level from European Parliamentary Research Service, to hold a public consultation ${ }^{14}$ in 2016, after the European Parliament Resolution on EU Law for an open, independent and efficient European administration. To reinforce its position, the European Parliament again called for action and adopted another Resolution in 2016. It consists of seven main justifications ${ }^{15}$ for the need ${ }^{16}$ to adopt a new legal instrument to ensure open, efficient, independent and transparent EU administration and EU administrative procedures including the importance of ensuring high administrative standards and the need for systematic approach.

${ }^{12}$ Hereinafter: Report 2018.

13 On 17 May 2016, Pavel Svoboda and Heidi Hautala on behalf of the JURI Committee submitted a question (Question for oral answer O-000079/2016) for oral answer to the Commission. "What are the reasons that have prevented the Commission from putting forward a proposal such as the suggested regulation, and when can a proposal be expected?"

Retrieved from https://www.europarl.europa.eu/doceo/document/O-8-2016000079_EN.html?redirect, [accessed on 20 April, 2020].

${ }^{14}$ Public consultation was open from 15 December 2017 to 9 March 2018, available in all official EU languages, online survey. Majority of responses were received from Dutch, Spanish and Italian nationals. Respondents were between 25 and 54 years old $(60 \%)$ and level of education- master's degree or above $(62.3 \%)$.

${ }^{15}$ Report 2018, p. 11-12.

${ }^{16}$ All institutions have expressed support regarding importance and need for new EU APA. 
The aim of public consultation was to survey public opinion in three directions: 1) on general attitudes towards the EU administration, 2) on personal experience in dealing with the EU institutions and 3) on further action that the EU should undertake in the area of EU Administrative Law. Parliament received 166 fully completed online responses from 20 Member States, 155 came from individuals and 11 from organisations. This paper, we would focus more on the analysis of the third section of the report. Survey is available at https://epthinktank.eu/2017/12/15/have-your-say-on-an-euadministrative-law/.

Citizens have frequent contact with the EU administrations, which is the result of expanding jurisdiction of the EU. An efficient EU administration is essential for the public interest. Otherwise it leads to maladministration, contradictory, inconsistent or unclear rules and procedures. Growing fragmentation of the current EU system, with its (highly complex current regulation) is problematic for European citizens. They find it difficult to exercise their right to good administration. Opinion on the degree of importance of eleven key administrative procedural rights and the three principles that were ranked the highest by the respondents were respect for fundamental rights, transparency and accountability.

$76 \%$ of the respondents see problems or shortcomings related to the functioning of the EU administration and/or application or enforcement of EU rights and principles. The results suggest that transparency, impartiality, independence and objectivity, as well as the obligation to give reasons for decisions remain problematic. There is a high degree of confusion and misconceptions among respondents regarding current applicable rules and procedures.

Incoherence and fragmentation in current system could potentially lead to loss of legal certainty in the EU legal system, decreased trust in the EU institutions, complexity of interaction between citizens and businesses, large degree of confusion and misconceptions, operational incoherence costs, difficulty to access EU administrative procedural rules, significant gaps in various areas.

Access to documents and requests for general information is the main reason to contact/ interact with the EU administration, followed by personnelrelated matters and issues related to public procurement. The European Commission $^{17}$ is the most frequently contacted institution (94\%), the European Parliament follows (80\%) and then come the EU agencies (48\%). There are differences and mixed opinions in experience with the EU

${ }^{17}$ It leads in the number of complaints received by the European Ombudsman and in the number of requests for access to documents. 
administration and level of satisfaction in contacts is low. Some respondents found the European Parliament to be more open and responsive than the Council or the European Commission. Respondents pointed to differences in bureaucratic cultures and administrative approaches.

There is a significant volume of EU administrative proceedings (e.g. 138 public authorities to which citizens can submit requests for information, 9200 requests for access to documents annually (data for 2016) submitted to $3 \mathrm{EU}$ institutions, 11 000-12 000 requests for access to documents by the EU institutions, bodies, agencies) (Report 2018, p. 4-6). Transparency in the administrative process and access to information remain problematic. Respondents find it difficult to manage and navigate through the EU administrative process. Review and correction of errors in administrative proceedings are considered the most difficult parts of the administrative proceedings. Administrative burden costs, lengthy procedures, difficulty in finding information and the quality of replies received were reported to be the key problems encountered. The main issue identified among citizens, who have negative or mixed experience with EU administration and its services, is related to the length of the procedure and also the lack of impartiality and fairness. This has a considerable impact on both positive and negative evaluation.

In conclusion, the majority of respondents support (82\%) adoption of a new legally binding EU legislative instrument for setting out minimum standards of administrative procedure and to reinforce the functioning of the EU administration (76\% support additional measures at EU level to reinforce the EU administrative procedure) ${ }^{18}$ and to simplify EU administrative rules and procedures. The main reasons (justifications) for necessary action at EU level are to improve efficiency $(57 \%)$ and transparency $(50 \%)$ of the EU administration.

In final section, we consider it important to emphasize the part of the question addressed to the European Commission which consist the statement of Pavel Svoboda:

"Especially in the current times, with Euro scepticism on the rise, citizens would enormously benefit from uniform procedural guarantees enforceable in the EU courts. Increased openness, transparency and accessibility of the EU administration will improve trust and the relationship between citizens and the Union's

${ }^{18}$ About potential additional measures (by type of regulatory action) see more Report 2018, p. 44. 
administration, and in that way we will also reinforce the legitimacy of the EU."19

\section{Influence of the Europeanization process on the National Administrative Procedures}

On the road to the opening of the European doors, the requirements of European administrative procedural law a number of challenges are raised. Regardless of national autonomy, the demands for equality and efficiency have led to significant European aspirations and influence on national administrative systems and procedures. The need for change in administrative and administrative procedural law has emerged through need to regulate the administrative procedure and to introduce a minimum of principles/guarantees/standards has arisen for reasons of inequality of treatment with regard to different legislative solutions of Member States.

Different directions of influences and pressures lead to remodelling of the administrative law by abandoning traditional concepts. Common principles vaguely influence these national traditions (Schmidt-Aßmann, 2013, p. 3435). Standards and principles are to be followed and applied with the aim of achieving efficacy of national administrative systems and complete legal protection of the citizens. Emphasis is, in the process, put on administrative and judicial capacities necessary for adequate transposition of the European law and its effect on national legislation (Đanić and Lachner, 2012, p. 163). National administrations find themselves in complex situations in which they need to balance between various influences since they are simultaneously exposed to streams demanding redefining of their administrative traditions.

The European administrative procedural law within which the European administrative procedure was developed has a great influence on the application of the general administrative procedure. It is the source of the unwritten procedural rules developed in the Member States, which enforce European substantive provisions. There are several aspects to the "reconnaissance" of EU administrative procedural law:

1) Procedural rules applicable to organizational units within European administration;

2) In policy areas such as the internal market and the environment, harmonization of procedural rules has been achieved through various regulations, directives, recommendations, resolutions,

19 Question for oral answer O-000079/2016 to the Commission, Rule 128 Pavel Svoboda, Heidi Hautala, on behalf of the Committee on Legal Affairs. Retrieved from https://www.europarl.europa.eu/doceo/document/O-8-2016000079_EN.html?redirect, [accessed on 22 April, 2020] 
3) If there are no uniform and harmonized rules, within EU law, a minimum standard of implementation for national states is ensured;

4) Set certain common procedural standards applicable in EU administration and national administrations, basic legal guarantees that form the basis of good administration, such as the right to fair procedure, the principle of impartiality, and the right to a timely decision (Klučka, 2007, p. 1049).

When discussing the EU administrative law, implementation and application of EU rights through cooperation between the institutions and the EU bodies and national level are implied (Schwarze, 1992, p. 143-145). Schwarze draws a distinction between direct and indirect administrative implementation of European law, emphasizing that administrative procedure in indirect administration lacks uniformity due to the principle of procedural autonomy (Schwarze, 2004, p. 86).

The European influence on national administrative law is closely related with the concept of shared government (Widdershoven, 2012, p. 245246). Many European proceedings are regulated by various administrative areas such as market competition, government supports, environment protection, medication sales, technology, and food safety. In these instances, cooperation between the EU institutions and national administrations is realised as a part of procedural frameworks in horizontal and vertical dimensions. National bodies face a dilemma as to whether domestic or/and EU law should be applied in particular cases considering there are different rules and practice. If the EU law does not contain any specific provision, it is for the national legal order of each Member State to establish procedural rules for actions intended to safeguard the rights of individuals, in accordance with the principle of procedural autonomy. ${ }^{20}$ The only restriction to the national procedural autonomy is that in each case, the application of national procedural law in the absence of EU procedural rules has to meet two conditions: principle of non-discrimination or equivalence and the principle of effectiveness (Verhoeven, 2011, p. 49). The application of the mentioned principles regarding the administrative procedure is considered as duty in order for the EU law to be applied effectively with its full effectiveness ensured (effectiveness (process equality) and effective legal protection (Effet utile)).

20 See Case C-3/16, Aquino v. Belgische Staat, ECLI:EU:C:2017:209; Case C-161/15, Bensada Benallal v Étatbelge, EU:C:2016:175; Case C-74/14, Etura sand Others $\mathrm{v}$ Lietuvos Respublikos konkurencijos taryba, EU:C:2016:42, Case C-413/12, Asociación de Consumidores Independientes de Castilla y León $v$ Anuntis Segundamano España SL, ECLI:EU:C:2013:532, Case C-29/15, Evelyn Danqua v Minister for Justice and Equality and others, ECLI:EU:C:2016:789. 
Even after having been enlisted in the national law, the norms of the EU law are still applicable and can be called upon in every national judicial and administrative proceeding. Regardless the national procedural autonomy, the demands for equality and effectiveness can lead to considerable influence over national administrative systems and procedures. The purpose is to achieve uniformity in application of procedural rules of conduct. But this uniformity might be illusory, because, although there might be a rule which is "the same" for a certain number of countries, it might not be interpreted equally, or applied equally (Harlow and Rawlings, 2010, p. 255).The solution lies in codification of fundamental process rules applicable in every country, the result of convergence of the administrative procedural law. According to the EU it is important to set the minimum of standards to satisfy and apply the common procedural demands. Supporting that is also the removal of different proceedings which negatively affect the functioning of the unique market.

\section{Conclusion}

Even though there are numerous discussions referring to benefits and drawbacks for regulating the administrative procedure on the EU level, codification of European administrative procedural rules are especially important and advisable for the purposes of achieving systematically encompassed and unified procedures. The mentioned suggestion would be used to purify the content and to enable easier access by individuals, civil society and economists, to achieve coherence between the rules and procedures, to fill in the missing blanks of the current system and to determine the function/purpose of administrative procedures. Codification would improve the quality and transparency of the EU's legal system and reduce the fragmentation of applicable rules (especially increased in sectorspecific legislation) and complexity of applicable rules.

Standardization would contribute to rationalisation and procedural simplifications, especially in sectorial areas. The role of the proposed EU APA to act as a subsidiary legislation lex generalis, when specific areas of administrative proceedings are not regulated by special laws, lex specialis or if sectorial rules do not state otherwise. Member states fear that there might be a contrary effect so they would be forced to change their national laws regarding the administrative procedures if EU APA would be binding for them. In addition to that, procedural national autonomy is to be emphasized here. However, the question arises as to which extent the national administrations should keep their autonomy, while at the same time ensuring the fulfilment of the European administrative procedural rules. In conclusion that the EU APA can serve as an example for national legislatures to consider the need for change or adjustments of their APA's in accordance of modern 
European principles, standards and procedural rights, especially right to good administration.

Administrative procedure demands joint regulation within the European administrative frame, as well as distribution of tasks regarding executive integration. Even though this form of administrative procedural law would not be directly applied in national administrations, since most of the states have their own regulations about the administrative procedure, its effects would definitely be evident in every area of activity governed by European law. This has already been accomplished in a number of sectorial areas, such as market competition, public procurements, asylum regulations, environment protection. One should, however, bear in mind that it is dangerous to assume equal or similar principles of public procedures will be applied in every member state and its administration.

The task of forming codified and unified procedural rules is not at all simple, since it demands a long-term quality solution on European level applicable to every member state, appropriate time of adjustment, analysis and comparison. A form of compromise could be found in creating codification of European administrative procedure especially in areas where there are significant differences between national rules for applying EU law. The solution lies in codification of fundamental process rules applicable in every country, which is the result of convergence of the administrative procedural law.

To conclude we will offer answers to following research questions:

I. Is codification even necessary? No, but it is useful and recommendable. Codifications per se are not a good option, if there does not exist normative and practical reasons for it. Do these reasons exist? Perception characterising administrative systems of member states is that the procedure is complex and incomprehensible to a regular citizen. Having this is mind, codification is positive, since it offers clarity and legal safety. Furthermore, the application of EU law occurs mainly within member states, and they each have their own APA, which makes codification unnecessary. This follows the Principle of Procedural Autonomy. However, there is no clear line between the traditional division on direct and indirect EU administration. This frequently occurs in composite administrative procedures, where administrative bodies of two or more member states and Union institutions collaborate in one procedure. It would be beneficial to formally regulate the collaboration.

II. Is there a viable legal basis for adopting the Proposal for Regulation on Administrative Procedure of the European Union the so-called EU 
APA? There is no explicit authority of the Union to adopt APA, though there exists derived authority from Article 298 Paragraph 1 of the TFEU. Since there are different opinions regarding this point of view in the academic community, the Union jurisdiction can be derived from the so-called general clause - Article 352 of the TFEU which defines the implied powers of the Union.

III. Should EU APA be binding only to EU institutions and/or member states when applying the EU law? According to the proposition of the Parliament from 2013, APA is to be applied in cases, where there is no proscribed code under the condition that sectorial rules do not offer less protection, and would be binding only for institutions, bodies, offices and agencies of the Union. Model Law is more farreaching in the sense that it offers two options, that is, two plans. According to plan A, the future code would be binding even for member states when applying the EU law, in other words when they work within the reach of the EU law. According to plan B, the code would not be binding for member states, unless it is so demanded by special sectorial rules or if member states choose to accept the code on their own. When considering composite administrative procedures, plan A of the Model Law is, according to our opinion, a more suitable choice for the EU APA. This means it should be binding even for member states, but only when working within the reach of the EU law. Parliament, however, still thinks differently and in Article 2 of the European Parliament Resolution for an open, efficient and independent European Union administration (2016/2610(RSP)) it officially indicates:

„1 This Regulation is to be applied on administrative activities of institutions, bodies, offices and agencies of the Union.

2 This Regulation is not to be applied on the activities of the Union administration during:

(a) legislative procedures

(b) judicial procedures

(c) procedures which lead to reaching unlegislated acts based directly on Treaties, delegated acts or executive acts. 3 This Regulation is not to be applied on administration of member states."

Codification of the European Administrative Law will only partly resolve the current issues and that what Parliament suggests is only a compromise to achieve the majority necessary for its adoption. Conclusively, the fact that there is still no reaction from the Commission is rather worrying. According to Frans Timmermans the Commission still remains: "open to be 
convinced about the opportunity of legislation providing for a horizontal framework of an EU administrative law, should a clear case be made as to its added value. Such a case, in the Commission's view, remains however to be made." 21

\section{References}

\section{Books and articles}

Cananea, G. (2018). A Law on EU Administrative Procedures: Implications for National Legal Orders. Retrieved from SSRN https://ssrn.com/abstract=3237951, [accessed on 24 April, 2020]

Carausan, M. (2016). Towards an Administrative Procedure of the European Union: Issues and Prospects. Administratio Acta Universitatis Danubius, 8 (2), 79-90.

Chalmers, D., Davies, G. \& Monti, G. (2019). European Union Law, Cambridge, United Kingdom: University Press.

Craig, P. \& De Búrca, G. (2011). EU LAW, Text, Cases and Materials, 5th edition, OUP Oxford.

Craig, P. (2013). Principles of Good Governance Common to Administrative Law in Europe. Presented at seminar "Developing Administrative Law in Europe: National Convergence or Imposed Uniformity?", The Hague. Retrieved from

http://www.aca-europe.eu/seminars/DienHaag2013/Table1_Craig_en.pdf, [accessed on 24 April, 2020].

Đanić, A. \& Lachner, V. Utjecaj pojave globaliziranog upravnog prava na nacionalne upravne sustave s naglaskom na hrvatsko upravno postupovno pravo, in Belaj, V. (ed.), Conference proceedings 2nd international conference Public administration development, Vukovar, Croatia, 11-12 May, 2012, 163-179.

Đerđa, D. (2014). Towards the Codification of the EU Administrative Procedural Law. In Koevski, G (Eds.) EU Administrative Law and its Impact on the Process of Public Administration Reform and Integration into the European Administrative Space of South East European Countries (pp. 79-83). Skopje, Maceonia: Centre for SEELS.

Đerđa, D. \& Jerčinović, A. (2020). Upravni postupak u pravu Europske unije:kodifikacijski izazov. Zbornik radova Pravnog fakulteta u Splitu, 57 (1), 85-126.

21 Retrieved from http://www.europarl.europa.eu/legislative-train/theme-union-ofdemocratic-change/file-eu-administrative-procedure, [accessed on 17 April, 2020]. 
Eliantionio, M. (2014). Judicial Review in an Integrated Administration: the Case of 'Composite Procedures'. Review of European Administrative Law, 7 (2), 65-102.

Evas, T. (2018). EU Law for an open independent and efficient European administration: Summary report of the public consultation. Brussels, European Union: EPRS, European Added Value Unit, 1-74. Retrieved fromhttps://www.europarl.europa.eu/RegData/etudes/STUD/2018/621830 /EPRS_STU(2018)621830_EN.pdf, [accessed on 20 April, 2020]

Harlow, C. (1996). Codification of EC Administrative Procedures? Fitting the Foot to the Shoe or the Shoe to the Foot. European Law Journal, 2 (1), 325.

Harlow, C. \& Rawlings, R. (2010). National Administrative Procedures in a European Perspective: Pathways to a Slow Convergence. Italian Journal of Public Law, 21 (2), 215-258. Retrieved from http://www.ijpl.eu/archive/2010/issues-21/national-administrativeprocedures-in-a-european-perspective-pathways-to-a-slow-convergence, [accessed on 26 April, 2020].

Harlow, C. \& Rawlings, R. (2014). Process and Procedure in EU Administration. Oregon, America: Hart Publishing, Oxford and Portland.

Hartley, T. (2004). Temelji prava Europske zajednice: uvod u ustavno i upravno pravo Europske zajednice. Rijeka, Hrvatska: Pravni fakultet Sveučilišta u Rijeci.

Hoffman, H. (2009). Composite Decision Making Procedures in EU Administrative Law. In Herwig Hofmann, C. H. \& Türk, A. H. (Eds.). Legal Challenges in EU Administrative Law Towards an Integrated Administration. (pp. 136-168). Cheltenham, United Kingdom, Northampton, MA, USA: Edward Elgar Publishing Limited.

Hofmann, H., Schneider, JP. \& Ziller, J. (2014). Administrative Procedures and the Implementation of EU Law and Policies. Contribution by the Research Network on EU Administrative Law (ReNEUAL) project on administrative procedure to the EU Commission's 'Assises de la Justice' conference in Brussels 21-22 November 2013 to the topic of EU Administrative Law, Law Working Paper Series Paper number 2014-02. 1-29. Retrieved from

https://orbilu.uni.lu/bitstream/10993/19855/1/N\%202014-

02_Herwig\%20C\%20H\%20\%20Hofmann_Administrative\%20Procedures $\% 20$ and $\% 20$ the $\% 20$ Implementation\%20of\%20EU\%20Law\%20and $\% 20 \mathrm{P}$ olicies\%20\%282\%29.pdf, [accessed on 5 June, 2020].

Josipović, T. (2009). Načela europskog prava u presudama Suda Europske zajednice. Zagreb, Hrvatska: Narodne novine.

Klučka, J. (2007). The General Trends of EU Administrative Law. The International Lawyer, 41(4), 1047-1054.

Koprić, I., Musa, A. \& Lalić Novak, G. (2011). Good Administration as a Ticket to the European Administrative Space. Zbornik Pravnog fakuleta u Zagrebu, 61 (5), 1515-1560. 
Kovač, P. (2016). The Requirements and Limits of the Codification of Administrative Procedures in Slovenia According to European Trends. Review of Central and East European Law, 41, 427-461.

Kovač, P. (2019). Potentials of Administrative Procedures as a Participatory Tool within Governance Models in Central and Eastern Europe. Danube 9 (4), 227-244.

Lenaerts, K., Maselis, I. \& Gutman, K. (2015). EU Procedural Law. Oxford University Press.

Ljubanović, B., (2016). Pravo EU u upravnom pravu i postupku, in Ljubanović, B. et al., Procesno-pravni aspekti prava EU (173-208). Osijek, Hrvatska: Pravni fakultet Osijek.

Meuwese, A. Schuurmans, Y. \& Voermans, W. (2009). Towards a European Administrative Procedure Act. Review of European Administrative Law, 2 (2), 3-35.

Petrašević, T. (2012). Primjena općih načela prava u praksi Europskog suda pravde. In conference proceedings "Načela $i$ vrijednosti pravnog sistema - norma i praksa", Marković, Goran and others (Eds.), East Sarajevo, Univeristy of East Sarajevo, Law Faculty, 793-807.

Ploeg van der, P. (2014). A general regulation of administrative procedure for the European Union, Retrieved from

https://acelg.blogactiv.eu/2014/12/17/a-general-regulation-of-

administrative-procedure-for-the-european-union/, [accessed on 20 April, 2020]

Ruffert, M. (2013). Common Principles and National Traditions: Which Perspective for European Administrative Legal Scholarship?, in Ruffert, M. (ed.), Administrative Law in Europe: Between Common Principles and National Traditions (pp. 215-221). Europa Law Publishing, Groningen.

Rusch, W. (2009). Administrative Procedure sin EU Members States. Paper presented on Conference on Public Administration Reform and European Integration, Budva, Montenegro, 1-10. Retrieved from

http://www.sigmaweb.org/publications/42754772.pdf, [accessed on 22 April, 2020]

Rusch, W. (2014). Citizens First: Modernisation of the System of Administrative Procedures in South-Eastern Europe. Croatian and Comparative Public Administration, 14 (1), 189-228.

Schmidt-Aßmann, E. (2013). Administrative Law in Europe: between Common Principles and National Traditions. In Ruffert, M. (ed.), Administrative Law in Europe: Between Common Principles and National Traditions. (pp. 3-13). Groningen: Europa Law Publishing.

Schwarze, J. (1992). European Administrative Law, Luxembourg: Sweet and Maxwell.

Schwarze, J. (2004). Judicial Review of European Administrative Procedure, Law and Contemporary Problems, 68 (1), 85-105 
Sever, T. \& Kovač, P. (2016). EU principles as a guide for modelling timely administrative procedures in Slovenia and Croatia. NALL maart 2016, DOI: 10.5553/NALL/.000024, 1-25. Retrieved from http://www.nall.nl/tijdschrift/nall/2016/03/NALL-D-15-00007.pdf, [accessed on 25 April, 2020].

Smith, M., (2012). Tracing the development of administrative principles in the EU: a possible new approach to legitimacy. In Trybus, M., Rubini, L. (Eds.) The Treaty of Lisbon and the Future of European Law and Policy. Edward Elgar Publishing

Verhoeven, M. (2011). The Costanzo Obligation. Intersentia: Ius Commune Europaeum (Book 93)

Vučetić, D. (2018). Global Trends in the Codification of Administrative Procedure, Zbornik Pravnog fakulteta u Nišu, LVII (78), 197-215.

Widdershoven, R. (2012). European Administrative Law. In Seerden, J. G. H. R. (ed.), Administrative Law of the European Union, its Member States and the United States, A Comparative Analysis (third edition) (pp. 245319). Intersentia: Ius Commune Europaeum (Book 109)

Wierzbowski, M. (2019). EU Member State Administrative Procedure and Impact of International and EU Rules: The Case of Poland. 1-10. Retrieved from

https://www.europarl.europa.eu/cmsdata/72866/Wierzbowskiv02.pdf[accesse d on 22 April, 2020]

\section{EU Law}

European Parliament resolution of 15 January 2013 with recommendations to the Commission on a Law of Administrative Procedure of the European Union (2012/2024(INL))

European Parliament resolution of 9 June 2016 for an open, efficient and independent European Union administration (2016/2610(RSP))

\section{Court of Justice of the European Union}

Case C-3/16, Aquino v. Belgische Staat, ECLI:EU:C:2017:209;

Case C-161/15, Bensada Benallal v Étatbelge, EU:C:2016:175;

Case C-74/14, Etura sand Others v Lietuvos Respublikos konkurencijos taryba, EU:C:2016:42,

Case C-413/12, Asociación de Consumidores Independientes de Castilla y León v Anuntis Segundamano España SL, ECLI:EU:C:2013:532,

Case C-29/15, Evelyn Danqua v Minister for Justice and Equality and others, ECLI:EU:C:2016:789

\section{Website references}


Answer given by First Vice-President Timmermans on behalf of the Commission Question reference: E 001249/2016. Retrieved from https://www.europarl.europa.eu/doceo/document/E-8-2016-001249ASW_EN.html?redirect, [accessed on 17 April, 2020]

Question for oral answer O-000079/2016 to the Commission, Rule 128 Pavel Svoboda, Heidi Hautala, on behalf of the Committee on Legal Affairs. Retrieved from

https://www.europarl.europa.eu/doceo/document/O-8-2016000079_EN.html?redirect, [accessed on 22 April, 2020]

European Parliamentary Research Service - European Added Value Unit; EU law for an open independent and efficient European administration Summary report of the public consultation, PE 621.830 - July 2018, Retrieved from

https://www.europarl.europa.eu/RegData/etudes/STUD/2018/621830/EPRS_ STU(2018)621830_EN.pdf, [accessed on 25 April, 2020]

European Added Value Assessment Law of Administrative Procedure of the European Union, pp. 1-26. European Added Value Unit (ed.), Brussels: European Union. 2012. Retrieved from

http://publications.europa.eu/resource/cellar/230193b6-a913-45a5-88536cb4ca9042cb.0004.02/DOC_1, [accessed on 25 April, 2020]

Galetta, DU., Hoffman, H., Puigpelat, OM. (2016). The context and legal elements of a Proposal for a Regulation on the Administrative Procedure of the European Union's institutions, bodies, offices and agencies. Directorate General for Internal Policies Policy Department C: Citizens' Rights and Constitutional Affairs Legal Affairs, pp. 1-52,

Retrieved from

https://u4unity.eu/document2/IPOL_STU(2016)536487.pdf, [accessed on 5 June, 2020]

https://free-group.eu/2016/02/09/better-administrative-making-when-theeuropean-parliament-pave-the-way-to-a-reluctant-european-commission/, [accessed on 1 June, 2020] 